MPIfG Working Paper 04/5

\title{
A New Form of Governance? Comparing the Open Method of Coordination to Multilateral Surveillance by the IMF and the OECD[1]
}

\author{
Armin Schäfer (as@mpifg.de) \\ Max Planck Institute for the Study of Societies
}

\begin{abstract}
The Open Method of Coordination (OMC) has received much attention in the recent EU-literature. The predominant view claims that the OMC is not only a new but also an effective policy-making instrument. This paper raises doubts about both claims by offering a comparison of soft law policy coordination in three international organizations. More specifically, this paper compares the European Employment Strategy - which was the first use of the OMC - to the Broad Economic Policy Guidelines of the EU, the OECD Economic Surveys, and the IMF Article IV Consultations. Based on expert interviews, it seeks to demonstrate that these procedures are forms of multilateral surveillance that do not differ in kind. Such a comparative analysis of the OMC refutes claims to its novelty. Having compared the four procedures, a more general model of multilateral surveillance consisting of six elements is generated that facilitates further comparisons. This paper concludes that governments select voluntarist procedures mainly to secure their own competencies rather than to realize common goals. Effective problem-solving is therefore not necessarily the dominant objective of soft law.
\end{abstract}

\section{Zusammenfassung}

Die EU-Literatur der letzten Jahre hat der Offenen Methode der Koordinierung (OMC) viel Aufmerksamkeit zukommen lassen. Die vorherrschende Sichtweise behauptet, dass die OMC nicht nur ein neues, sondern auch ein effektives Instrument der Politikgestaltung sei. Dieser Aufsatz stellt beide Aussagen infrage, indem es einen Vergleich verschiedener soft law-Verfahren von drei internationalen Organisationen vorlegt. Im Einzelnen vergleicht dieses Papier die Europäische Beschäftigungsstrategie - mit der die OMC zuerst entstanden ist - mit den Grundzügen der Wirtschaftspolitik der EU, den Länderberichten der OECD sowie den Artikel-IV-Konsultationen des Internationalen Währungsfonds. Auf der Grundlage von Experteninterviews wird gezeigt, dass alle vier Verfahren multilateraler Überwachung zugeordnet werden können und kein kategorischer Unterschied zwischen ihnen besteht. Eine solche vergleichende Analyse widerlegt die angenommene Neuheit der OMC. Aufbauend auf dem Vergleich der vier Verfahren wird dann ein allgemeines Modell multilateraler Überwachung entwickelt, welches aus sechs Elementen besteht und zukünftige Studien erleichtern wird. Dieser Aufsatz schließt mit der Beobachtung, dass Regierungen voluntaristische Verfahren eher deshalb wählen, um ihre eigenen Kompetenzen zu verteidigen als gemeinsame Ziele zu verwirklichen. Effektive Problemlösungsfähigkeit erscheint nicht als vorrangiges Anliegen von soft law.

\section{Contents}


3.3 European Union I: Broad Economic Policy Guidelines

3.4 European Union II: The European Employment Strategy

Literature

\section{Introduction}

The study of the European Union has moved from the question of what factors explain the integration process to how the European polity functions. While the former question was at the heart of the debate between neofunctionalism and intergovernmentalism, scholars in the nineties began to ask how policy-making works in this multi-arena, multilevel system of governance, analyzing the problem-solving capacity of the EU (Grande 2000: 11-12; Jachtenfuchs 2001). Taking this development one step further, the question emerged how the European level impacted on pre-existing national politics, policies, or even polities. Rather than looking at the reasons why states choose integration, more recent analyses have focused on how decisions in favor of integration, once taken, feed back into the national arena. Accordingly, we have witnessed shifting foci from integration to governance to "Europeanization" (cf. Risse/Cowles/Caporaso 2001).[2]

As a consequence, less attention has been paid to comparing EU policy-making to that of either states or other international organizations. Since the European Union is treated as a unique entity - a construction sui generis - comparisons to other political systems seem futile. However, as Hix (1998: 54-55) points out, many features of the EU are open to comparison if we do not aspire to find a general theory of the Union at large.[3]

In the literature on the Open Method of Coordination (OMC) the neglect of systematic comparisons is particularly pronounced. Attention is paid almost exclusively to the question of whether and to what degree this mode of governance enables policy-learning or even a convergence of welfare state policies to occur (Ferrera/Hemerijck/Rhodes 2000: 67; Régent 2002: 20).[4] Despite a lack of empirical evidence of these effects, these studies maintain that the OMC was created for these purposes and will achieve them in due course. Thus, many studies implicitly follow a functional logic that accounts for the causes in terms of their (anticipated) effects.[5] For example, Radaelli (2003: 52) maintains that the OMC as an "ideal type" could deliver better governance, although he cites hardly any evidence that it has already done so. In fact, he states that the actual practice differs considerably from the conceived ideal. Even though it is frequently noted that the $\mathrm{OMC}$ is a form of peer review, there are no studies to date comparing it to similar procedures in international organizations. While scholars have detected a family resemblance with peer review, we still lack an understanding of how similar or dissimilar these procedures actually are.

This paper seeks to fill this void by comparing the European Employment Strategy (EES) - the first use of the OMC - to the Broad Economic Policy Guidelines of the EU, the OECD Economic Surveys, and the IMF Article IV Consultations. It seeks to show that, 
despite differing emphasis, they all are procedures of multilateral surveillance. They have common features distinguishing this mode of policy-making from other ones, such as the traditional Community Method of the European Union (see section 5).

The argument proceeds in five steps. The next section looks briefly at some of the expectations directed at the Open Method of Coordination. However, it points out that we lack a coherent understanding of what kind of policy instrument the OMC is. Therefore, the subsequent section juxtaposes four instances of economic policy coordination in international organizations. This comparison is based on 30 expert interviews conducted by the author in 2002 and 2003. Staff of the OECD, the IMF and the European Commission as well as of national ministries were asked about the conduct of each procedure. Based on this comparison, section 4 identifies six common elements of multilateral surveillance. They delimit this form of governance from other ones, particularly the Community Method. This leads in section 5 to the question of why the EU, from the 1990s onwards, increasingly relies on soft law to achieve its goals. A preliminary answer is that soft law offers distinct advantages mainly for national governments. They are enabled to reach an agreement without having to fear its consequences. Finally, the conclusion considers what we can learn about the effectiveness of the OMC by comparing it to policy coordination by other organizations.

\section{Promises of the OMC}

With the March 2000 Lisbon summit, the OMC became the key to action in areas where a treaty base was lacking but a common concern was perceived. Currently, it is applied to more than ten policy areas, e.g. social inclusion, education, pensions, and R\&D policies (Hodson/Maher 2001: 726). The Lisbon European Council defined the core elements of the Open Method of Coordination. It involves:

- $\quad$ fixing guidelines for the Union combined with specific timetables for achieving the goals which they set in the short, medium and long terms;

- $\quad$ establishing, where appropriate, quantitative and qualitative indicators and benchmarks against the best in the world and tailored to the needs of different member states and sectors as a means of comparing best practice;

- $\quad$ translating these European guidelines into national and regional policies by setting specific targets and adopting measures, taking into account national and regional differences;

- $\quad$ periodic monitoring, evaluation and peer review, organized as mutual learning processes.

Moreover, the $\mathrm{OMC}$ is seen as the appropriate way to secure the new strategic goal agreed upon in Lisbon. Until 2010, the European Union will strive to become "the most competitive and dynamic knowledge-based economy in the world, capable of sustainable economic growth with more and better jobs and greater social cohesion." A particularly important role is assigned to modernizing the European Social Model through the OMC. The ultimate goal is full employment in Europe (European Council 2000: $§ 5+6$ ).

Yet, it is not only politicians who pin their hopes on the OMC. In the scientific literature, the following expectations are formulated (see also de la Porte/Pochet 2004). The OMC is supposed to:

- enhance policy-learning through benchmarks and best practices (Pochet/Porte/Room 
2001: 293; Zeitlin 2004);

- transform bargaining into deliberation (Eberlein/Kerwer 2002) and "eventually create a European public sphere: a real-world approximation to the Habermasian 'power-free' discursive space that gives free rein to the public interest precisely because it is not directly entangled in the strategic games of legally enforceable rule-making" (Sabel/Zeitlin 2003: 25);

- foster social policy convergence in the long run (Trubek/Mosher 2001: 14-15; Rodrigues 2002: 22);

- help create a new balance between supranationalism and intergovernmentalism (Jacobsson 2001: 2);

- build Social Europe (de la Porte/Pochet 2002a); or

- "recalibrate" European welfare states (Ferrera/Hemerijck/Rhodes 2000).

However, there is to date no convincing empirical base for evaluating the effectiveness of the OMC in terms of its legislative output or outcomes.[6] Proving its effects is methodologically difficult because it is hard to establish what would have happened without it, and possible positive effects only become visible in the medium to long term. Even the official evaluation of the EES after five years stresses the difficulty of isolating its effects from the general economic cycle on the one hand and from policy initiatives that originated from different sources on the other hand (cf. European Commission 2002c; Borrás/Greve 2004: 331-332).

An important empirical study shows that in Denmark and Sweden (two good performers according to the Commission) the EES procedures have little direct bearing on domestic policy-making. The authors use the notion of a "diplomatic mission" to describe the relation between European and national politics (Jacobsson/Schmid 2002: 87). From the perspective offered in this paper, their results do not seem too puzzling. Rather than focus on the national impact of this mode of governance, we first have to understand what kind of policy instrument the $\mathrm{OMC}$ is. Thus, the following sections propose a hitherto neglected approach. I seek to better understand the Open Method of Coordination by analyzing similar procedures of multilateral surveillance of the IMF and the OECD.[7] While the similarity of the OMC to these organizations' practices has been noted (Borrás/Jacobsson 2004: 188) and though Wallace (2000: 32) calls the OMC the "OECD technique," no systematic comparison exists to date. This paper seeks to demonstrate that the OMC does not differ in kind from other procedures of multilateral surveillance, even though it is more stringently applied. Since available evidence indicates that neither the OECD nor the IMF (where financial incentives are lacking) have a strong impact on national policies, this paper also questions the OMC's putative effectiveness.

\section{Procedures of Multilateral Surveillance}

This section gives a summary of how international organizations monitor their members' behavior. Therefore, the OECD's Economic Surveys, the IMF's Article IV Consultations, the Broad Economic Policy Guidelines (BEPG) and the European Employment Strategy of the European Union will be examined. This section is based on expert interviews and a study of the available documentation on the organizations' work. The aim is to construct for future use a general model of multilateral surveillance which invites further empirical analyses. 
Ever since its formation in 1961, the OECD has sought to ensure that its member states follow the code of conduct for sound economic policies laid down in the OECD Convention. This is achieved through regularly monitoring and evaluating the economic situation in the member states and their respective policies. Thus, every 12 to 18 months the OECD produces an Economic Survey for each country. Such a report results from a detailed surveillance procedure (cf. Marcussen 2004).

The OECD's multilateral surveillance is a two-tiered process. [8] It consists of a preparatory and a discussion phase. Any country report is prepared by the Secretariat or, more specifically, a country desk in the Economics Department of the organization. The process starts with a detailed questionnaire being sent to the country concerned. In answering the questionnaire, national administrations inform the OECD staff about recent economic developments, their forecasts and the underlying assumptions. Moreover, a country can state how it strives to solve economic problems or which policy initiatives are currently being prepared.

However, since data demands explanation, a staff team visits the country for a 'scouting mission.' On site they gather further information and meet officials from key ministries, the central bank, social partners and scientific institutes to gain a better understanding of the host country. During the scouting mission few political discussions take place. Instead, the mission is geared towards obtaining relevant information. The OECD staff then prepares a first draft for the country survey. This draft already includes an assessment of major problems and an evaluation of the appropriateness of a government's action. Any country survey follows a general structure of (1) assessment and recommendations: recent trends, prospects and macroeconomic policy requirements; (2) an overview of structural policy developments, key challenges and implementation of structural reforms; and (3) a country-specific special chapter (e.g. on public sector spending, aging, environmental sustainability) (Nottage 2002: 21-22).[9]

Approximately three months after the scouting mission another one is scheduled. It follows up on the first and is based on the draft Economic Survey. The OECD staff specifically addresses a country's weaknesses and vulnerabilities. There is a twofold purpose to the second mission: up-dating information and initiating policy discussions. A mission ends with bilateral discussions between the OECD and the national authorities. The OECD team presents its assessment to high-ranking national officials, who respond in turn.[10]

After returning to Paris, the team then prepares a final draft of the Economic Survey. It will be distributed to all member countries about four weeks prior to the multilateral discussion in the Economic Development and Review Committee (EDRC). At this point, the bilateral preparatory phase ends.

The discussion then moves to the EDRC.[11] Each member state sends representatives to this committee, which is an intergovernmental body that decides on the principle of unanimity. Crucially, the EDRC is responsible for publishing the Economic Survey, not the OECD Secretariat. Two reviewers are assigned to every examined country to lead the discussion. An EDRC meeting usually begins with a statement of the country under review. A government delegation (ten to 14 people) explains its view of the OECD staff's report, pointing out disagreements, possible mistakes and generally defending the course 
chosen. Subsequently, the reviewers get the chance to pose questions before a general discussion starts. The entire procedure is motivated by peer review and peer pressure. Any government has to come up with reasonable arguments for its behavior and defend its own policies in the light of probing questions. While diplomatic in tone, participants do not shy away from voicing concerns and critique. These multilateral discussions are directed at redrafting the survey in a way that all governments can eventually agree to it. Therefore, the chair produces a summary of the discussion, on which the survey's redrafting is based. A country examination in the EDRC usually lasts between half a day and a day.

The redrafting takes place during the next couple of days. In this regard, the first section of the Economic Survey - "assessment and recommendations" - is all that counts as it summarizes the OECD critique. Any country tries to amend this section of around twenty pages as much as possible, haggling over the general message adopted and even over single phrases - a feature common to all four procedures. However, once the OECD staff and the examined country reach an agreement, the redrafted country survey will again be sent to all other members. It can only be published after they too have consented. This procedure serves as a safeguard against excessive redrafting and thus a change in the stance the EDRC as a whole had taken.

Finally, an Economic Survey is published. A press conference announces its publication to draw attention to it. The publication ensures that public pressure supplements peer pressure.

\subsection{IMF Article IV Consultations}

The International Monetary Fund is best known for the credits it grants to countries facing financial crisis. In these cases, the IMF has considerable power to impose its policy advice. However, the most advanced countries hardly ever have to make use of their drawing rights and, therefore, it is much harder to influence their economic conduct (Bordo/James 2000: 24). At the same time, it seems particularly desirable to make sure their policies are not in conflict with the general growth objective of the world economy because their behavior invariably has the greatest impact on this. The means chosen for the coordination of national policies are, once more, monitoring and peer pressure. The IMF is requested to exercise "firm surveillance" of the exchange rates of its members who, in turn, shall provide the Fund with "all the information necessary" (Articles of Agreement, Art. IV). Both goals are achieved by an annual multilateral surveillance procedure. These so-called Article IV Consultations were introduced with the second amendment of the original IMF Articles of Agreement that came into force in 1978 (Boughton 2001: 68, 88-89; de Vries 1985: chapter 43).

As with the OECD Economic Surveys, we can distinguish a preparatory and a discussion phase. The procedure also involves a mission, bilateral consultations, a staff report with recommendations, and multilateral discussions. As a first step, the country desk produces a 'mission brief' with a general assessment of the reviewed country. Various departments check this document to make sure it is in line with the overall IMF policy. Already at this early stage, the stance of the staff team takes shape (Crow/Arriazu/Thygesen 1999: 24).

The actual mission to the member country begins roughly two weeks later. An IMF delegation, consisting of four to five people, visits the country for one or two weeks. Very much like the OECD team, they meet officials from different ministries, the central bank, 
the social partners, and scientists. Originally, the IMF also sent a questionnaire to gather information, but nowadays this is done during the mission itself. Country officials inform the IMF delegation about recent economic and political developments, planned activities and their current forecast for taxes, unemployment, public spending, etc. A good deal of the work done during a mission consists of "getting the numbers right."[12] The mission concludes, however, by bilateral discussions with high-level officials (both the Minister of Finance and the head of the central bank usually participate). The IMF delegation presents its 'concluding statement,' which summarizes its views on fiscal and economic policy and contains policy recommendations. In turn, the officials comment on the concluding statement. If there are differences in opinion, the IMF team has to report on them afterwards.

In Washington, the head of the mission writes a 'back-to-office report' that informs the Fund management of the mission's results. Additionally, the country desk writes a staff report containing (1) information on the economic situation of the reviewed country, (2) policy recommendations, (3) an account of the policy discussions, and (4) the final 'staff appraisal.' The preparatory phase ends with the staff report. About a month later, the Executive Board discusses this report. This is the occasion when multilateral discussion takes place. However, this peer review is less formalized than in the OECD's EDRC as there are no pre-appointed reviewers and no government delegation participates. Instead, the permanent representatives of the reviewed country take on that role. Member state's policies are discussed for about half a day on the basis of the staff report.

Unlike the OECD, there is no need to come to an agreement. In many cases, Executive Directors disagree and different views enter the chair's 'summing up,' a document subsequently sent to the national authorities.[13] This summary account is also published as a Public Information Notice. Discussions are freed from the need to reach a consensus and can therefore be frank. Another difference to the OECD is that the Staff Report is published unchanged by and independently of the member states. The EDRC - that is, the member states - publish an OECD Economic Survey. In contrast, in Article IV Consultations, the Public Information Notice and the Staff Report are published separately to allow for differences. Hence, the IMF is transparent in terms of its discussion and how views differ.[14] Moreover, member states can voluntarily consent to having the mission's 'concluding statement' published. An annual consultation cycle concludes with an IMF press conference reporting its results and announcing the publication of the relevant documents.

\subsection{European Union I: Broad Economic Policy Guidelines}

The following two sections turn to multilateral surveillance in the European Union. There are broad similarities in the way the EU strives for economic policy coordination with the OECD and the IMF despite differences in the institutional setting. After assessing the Broad Economic Policy Guidelines (BEPG) - an early parent to the OMC introduced with the Maastricht Treaty - in this section, the next section examines the European Employment Strategy.

The BEPG have gained in importance since they were introduced with the Maastricht Treaty. Today, they are supposed to be at the heart of the European Union's economic policy coordination (cf. European Commission 2002b: 6): 


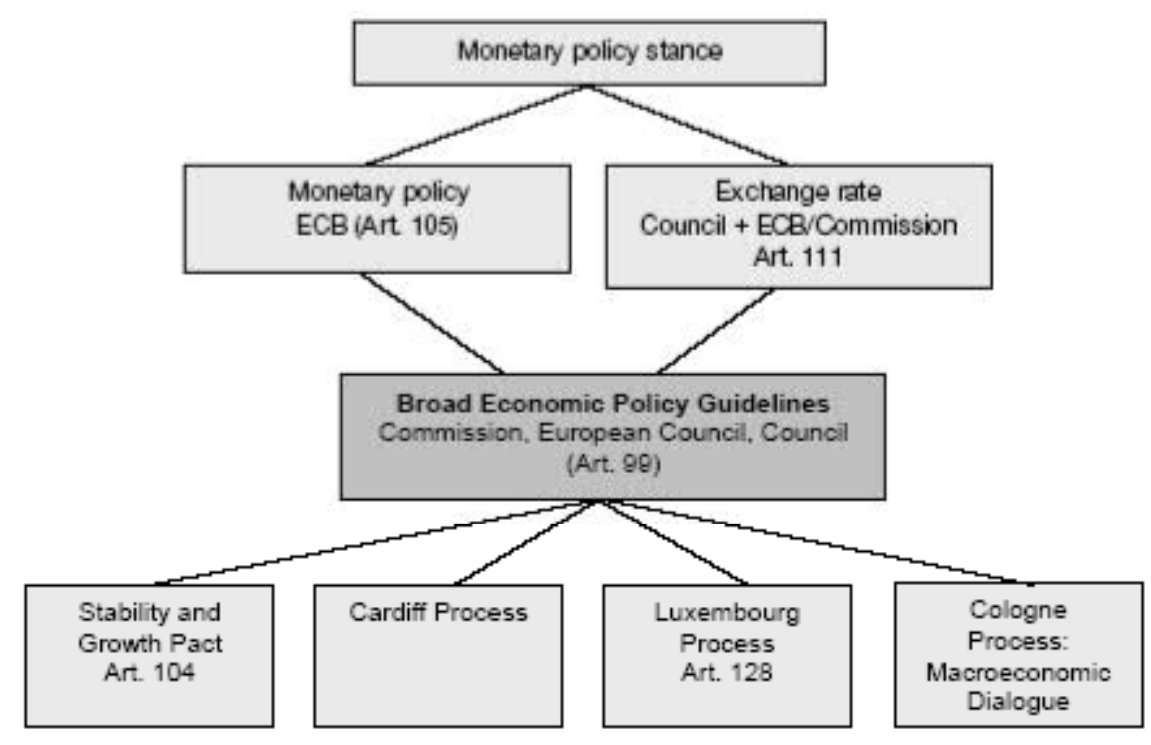

The central role of the BEPG is to ensure a sound policy mix for the European economy as a whole through "multilateral surveillance" (TEC, Art. 99/3) (cf. Hodson 2004). They deal not only with member states' policies in isolation but also with their combined effect on inflation, growth, and unemployment. Accordingly, the BEPG contain a general as well as a country-specific part each year. They focus on macroeconomics, wage policy, public finances, labor, product and financial markets, entrepreneurship, etc. The main instrument employed is the issuing of recommendations. For the period from 2003 to 2005 , there are 28 general recommendations plus three to eleven specific ones for each country (Council of the European Union 2003). A ranking of the member states follows from the number and type of country-specific recommendations. Such a ranking can increase the public pressure on governments.

As with the Article IV Consultations and the European Employment Strategy, the Broad Economic Policy Guidelines follow a yearly cycle, which in this case starts in January. It also consists of two parts, a policy formulation and a policy implementation/ evaluation phase. The first commences with the Spring Summit of the European Council, which defines general political guidelines for the EU on the basis of a 'Key Issues Paper' from the acting Presidency. In April, the European Commission presents its draft for the Broad Economic Policy Guidelines, taking into account the European Council's conclusions. It entails both kinds of recommendations. As with the OECD and the IMF, the Secretariat has the task of producing a template for the subsequent discussion. While producing its draft, the Commission relies on bilateral contacts with national administrations to gather the required information. There are no missions as the exchange of data happens continuously.

Eventually, the ECOFIN Council has to adopt the BEPG. However, this is normally a formal act involving no further discussion because the substantial work and policy discussions have already taken place in three committees preparing the ECOFIN's work. These committees are the Economic Policy Committee (EPC), the Economic and Financial Committee (EFC) and the ECOFIN Alternates. They are the primary location for multilateral discussions and peer pressure, even though these are less formalized than in the OECD's Economic Development and Review Committee. In practice, each member state mainly considers those recommendations that relate to it directly. National representatives try to correct mistakes and water down criticisms. The process of revising 
the BEPG - which mainly means redrafting country recommendations - resembles the OECD's redrafting of an Economic Survey subsequent to the EDRC meeting. Most discussions take place between the member country concerned and the Commission, but all others monitor and, if need be, amend the changes introduced. In controversial cases, there is an open discussion, but ultimately - also in line with the OECD - a consensus has to be reached.[15] The procedure allows for adjustments but limits their magnitude as Table 1 demonstrates:

\section{Table 1 BEPG Country Recommendations 2002}

\begin{tabular}{l|ccc} 
Country & $\begin{array}{c}\text { Number of } \\
\text { recommendations }\end{array}$ & $\begin{array}{c}\text { Total number of amended } \\
\text { recommendations }\end{array}$ & $\begin{array}{c}\text { Number of substantially } \\
\text { amended recommendations }\end{array}$ \\
\hline Austria & 8 & 4 & 4 \\
Belgium & 10 & 6 & 4 \\
Denmark & 6 & 1 & 1 \\
Finland & 8 & 1 & 0 \\
France & 10 & 4 & 4 \\
Germany & 12 & 8 & 6 \\
Greece & 13 & 3 & 1 \\
Ireland & 8 & 1 & 1 \\
Italy & 11 & 5 & 3 \\
Luxembourg & 5 & 0 & 0 \\
Netherlands & 6 & 1 & 1 \\
Portugal & 11 & 4 & 3 \\
Spain & 12 & 4 & 3 \\
Sweden & 6 & 1 & 1 \\
UK & 6 & 2 & 1 \\
Total & 132 & $45(34 \%)$ & $34(26 \%)$
\end{tabular}

Source: European Commission (2002a). Yet, there seem to be even less changes for the 2003-2005 $B E P G$. See the documentation of the Commission's and the Council's recommendations in European Commission (2003).

After prior discussions in the committees, the Council accepts the Broad Economic Policy Guidelines, forwarding a report to the European Council that then formally concludes its work on the BEPG. In June, the Council formally adopts them. This is when the policy formulation phase ends.

Subsequently, during the second half of the year, the implementation and evaluation begins. Governments are supposed to take the BEPG into account in national policymaking. Specifically, they are urged to take the recommendations seriously. Yet, as with all soft coordination processes, no transfer of sovereignty exists. All action has to be taken at the national level, the European level only monitors and comments on what happens. This task falls to the European Commission that has to keep member states' policies under firm surveillance.

Accordingly, the Commission presents the 'implementation package' in January - ending the yearly cycle. It consists of an implementation report of the BEPG, a progress report on the common market strategy, and a report on the functioning of the Community product and capital markets. The surveillance of economic policy through the BEPG thus differs from both the OECD and the IMF in that it monitors more closely whether and how states follow the recommendations given. In the other organizations this follow-up is less consistent. Therefore, there is a stronger basis on which to criticize governments for not sticking to their own commitments since they themselves had agreed to the recommendations. At the same time, the BEPG are not as stringently targeted at peer pressure as OECD surveillance is. 
As mentioned in the introduction, the European Employment Strategy was the first instance of the OMC - although this name did not exist at the time. However, of the four cases of multilateral surveillance compared in this paper, it was the last to be conceived. The EES, too, is a process of reciprocal monitoring of national policies. It is probably the most elaborated version of multilateral surveillance because it specifies detailed goals (Employment Guidelines), asks member states to draw up National Action Plans (NAPs), entails recommendations, and makes use of indicators to review their implementation. The EES was created in 1997[16] and has passed through five full cycles before being transformed from an annual to a triennial cycle in 2003. Additionally, it was synchronized with the BEPG schedule to harmonize both procedures. As it is too early to assess how this change influences the process, the focus here is on the annual cycle.

In line with the other processes, the international organization's secretariat initiates a cycle. In September, the European Commission presents a draft for the Joint Employment Report (JEP), which discusses the general employment outlook for the Union and the member states. Usually, it contains two to six recommendations for each country. These recommendations are based on an evaluation of the NAPs and the actual policies pursued. They can lead to a ranking of member states and therefore are used for 'naming and shaming.' When the recommendations were first introduced, member states feared negative consequences domestically. However, as Meyer (2003) shows, recommendations receive hardly any attention in national newspapers and the general public has presumably never even heard of the European Employment Strategy.

The Commission's draft of the Joint Employment Report has to be accepted by the Council. In line with the Broad Economic Policy Guidelines, various committees discuss it first. The most important one is the Employment Committee (EmCo). Yet the Economic Policy Committee also comments as the Employment Strategy has to be consistent with the BEPG. Both committees have to accede to the JEP before the Council can approve in autumn. The European Council considers the economic situation in the Union as a whole and shall adopt conclusions thereon (TEC, 128/1). The policy formulation phase ends in January when the Council agrees upon a new set of Employment Guidelines as well as the recommendations.

Over the next few months, member states have to transform the objectives defined by the guidelines into a National Action Plan. Ideally, writing the NAP is a concerted effort that brings together various actors (e.g. from different ministries and the social partners) to strategically set out the goals for employment policy. However, empirical studies cast doubts on how embedded this exercise is in national policy-making (cf. Büchs/Friedrich 2004). In May, each country sends its NAP to the Commission, which analyzes them and incorporates its evaluation into the drafting of the JEP.

EmCo discusses these documents in June. Members assess each other's NAP in a peer review called the 'Cambridge Process.' Biagi (1998: XXIX) describes this peer review as very similar to the EDRC procedure: There is a cross-examination, whereby each country examines and is examined by its peers. On this occasion, multilateral surveillance proper takes place, although less than an hour is spent on each NAP (Trubek/Mosher 2003: 48). In addition to this multilateral exchange, there are bilateral ones, with the Commission and the member states concentrating on sections relating to individual countries in the draft JEP. Similarly to the OECD's second mission, their purpose is to make sure all data is correct and up-dated. The Commission then produces a final draft of the JEP before it 
is handed over to the committees in September, when the cycle is completed.

Whereas EU states have dynamically developed the EES into elaborate soft coordination with many specific goals and more then a hundred indicators measuring progress, multilateral discussion is not as strong as in the OECD. However, discussion in the committees and even in the Council is more steady and frequent than in the OECD. Noaksson and Jacobsson (2003) argue that the policy advice provided by the Commission and the Council is less detached from the countries experiences at home than is the case with OECD recommendations (cf. also Visser 2002). They distinguish analytically between the OECD as an expert organization and the EU as a political one. The latter is more able to adapt to new themes and concerns of the member states. However, there is a downside to politically malleable procedures. The EES depends on a supportive actor constellation. If this vanishes, the process could well run aground (see section 6).

\section{A Model of Multilateral Surveillance}

Multilateral surveillance rests on peer review, i.e. on the mutual monitoring and evaluation of national policies by other governments. It is targeted at bringing states to behave in accordance with a code of conduct or specific goals, at developing common standards and at acquiring best practices through international comparison. Precisely because there are no sanctions, this mode of governance builds on a cooperative effort to criticize existing policies and generate new ones. In the absence of other means of leverage, any impact on national governments has to result from the (mild) pressure of having to justify one's action in the light of a common evaluation of the compliance of this action with joint goals (cf. Nottage 2002: 4). This was already noted by an early study on the OECD:

"The significant result of having the members compare, analyze, and discuss their policies is a better understanding of each other's problems and a growing recognition of the interdependence of national policies. This is a rather impalpable process that nonetheless has recognizable effects. One effect, to use the analogy of a physical phenomenon, is a kind of 'osmosis' - a diffusion of ideas, a better understanding of one country's policies by responsible officials in other countries, and the anticipation of more sympathetic response by others to these policies (and vice versa). This calls for the periodic personal contacts that also engender mutual appreciation and trust. Participants in OECD meetings agree that this intangible element has given them much better insight and influenced their thinking materially." (Aubrey 1967: 144)

The possible effectiveness of multilateral surveillance depends on establishing peer pressure and persuading reluctant actors. Pagani (2002: 5-6) lists three elements which can foster peer pressure: “(i) a mix of formal recommendations and informal dialogue by the peer countries; (ii) public scrutiny, comparisons, and, in some cases, even ranking among countries; and (iii) the impact of all the above on domestic public opinion, national administrations and policy makers." More specifically, based on the preceding sections, we can identify six elements that define this mode of policy-making, distinguishing it from the Community Method (cf. Figure 2). They apply to all four surveillance procedures described above. 


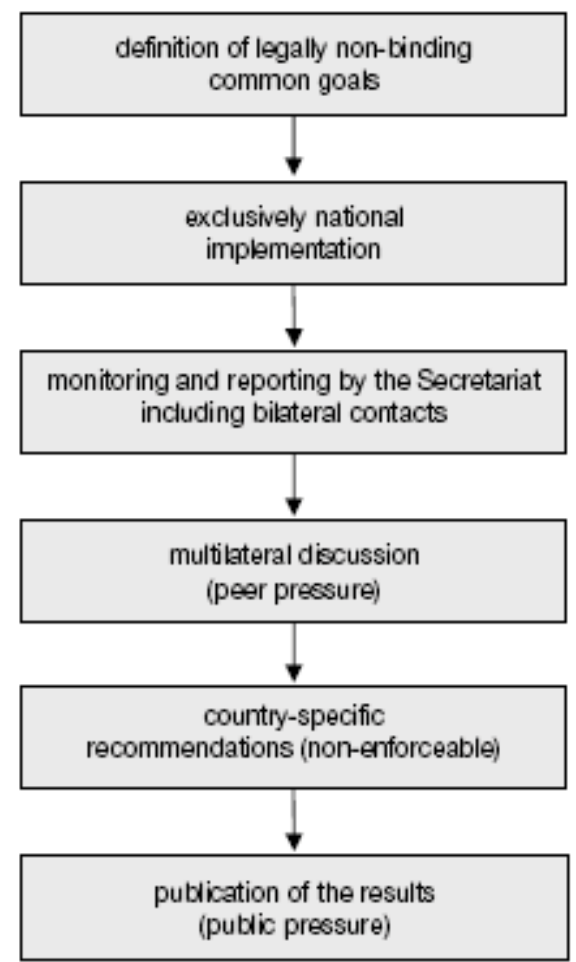

Whenever these characteristics are present, we can speak of soft coordination through multilateral surveillance.[17] Of course, each procedure differs in its emphasis on particular elements, and those described above also differ in their application. However, these are variations in style, not in kind.

What are these differences? Multilateral surveillance in the EU defines common goals more precisely. Rather than just relying on a general code of conduct, the EU makes use of concise guidelines. It also more stringently monitors their implication. The EU processes aim at continuously advancing clearer goals and more systematic monitoring devices (e.g. through indicators or best practices).

Both the IMF and the OECD are less specific in defining goals and, consequently, monitoring is less detailed. This is especially true of the Article IV Consultations, which, however, supersede the other procedures in terms of transparency since even the staff report itself is published. Emphasis is thus put on public pressure rather than peer pressure, while the Executive Board's discussions are quite detached from national policy-making. In terms of peer discussion, the IMF Consultations clearly fall short of the other procedures.

In general, the OECD procedure most resembles the OMC. One major difference is, of course, that, for the latter, governments have to draw up National Actions Plans, which are supposed to increase their commitment. Discussions in the EDRC are, however, more consistently geared towards peer review and peer pressure as they rely on an elaborate process of cross-examination. The downside of this procedure is that the discussion of any particular country is only sporadically intense, namely every 12-18 months, when a review or missions are due. Both the EES and the BEPG entail more continuous debates. Economic Surveys receive a relatively high attention in the national media and could at times increase public pressure.[18] 
Additionally, OECD Economic Surveys are by far the most comprehensive and detailed accounts of national economies, followed by the IMF Staff Report. An OECD Economic Survey offers a comprehensive review of economic trends, recent policies, and current reform agendas. They are good guides to a country's political and economic outlook. In contrast, both the Joint Employment Report and the Broad Economic Policy Guidelines only have relatively short sections on each member state. More emphasis is put on the EU economy as a whole.[19]

In sum, I would argue that with the European Employment Strategy and the Broad Economic Policy Guidelines multilateral surveillance is applied more stringently than with either the Article IV Consultations or the Economic Surveys (see also Begg/Hodson/Maher 2003: 71). While EU member states do rely on instruments employed by international organizations, they have been more willing to reinforce them through clearly defined, testable guidelines. The difference remains a gradual rather than categorical one, however.

\section{Why Soft Law?}

The empirical account of the previous sections leads to the conclusion that the Open Method of Coordination is but a special form of multilateral surveillance. It does not differ in kind from the instruments deployed by international organizations. As such, it can be described as intergovernmental and voluntaristic (cf. Streeck 1995):[20] Governments can choose whether and to what degree they take European guidelines into account. With the OMC neither the European Commission nor the European Court of Justice can take decisions. Instead, the prerogative for action rests with the member states. The European Parliament enjoys a marginal influence at best. Furthermore, the goals agreed to at the European level are not binding, and there are no sanctions other than 'naming and shaming' if a national government decides not to act on them.

The OMC is a new form of governance only in the context of the European Union: a less supranational, less integrationist one than the Community Method, which - in contrast is characterized by a) the Commission's monopoly of the right of initiative; b) widespread use of qualified majority voting in the Council; c) an active role for the European Parliament; and d) the uniform interpretation of Community law by the Court of Justice (cf. Wallace 2000: 28-29). At the same time, OMC-type soft policy coordination has been well established in the OECD and the IMF for decades. This raises the question of why the European Union of the 1990s was more ready to rely on the same instruments as other international organizations?

Multilateral surveillance was introduced to the OECD and the IMF at times when there was little agreement in substance. Similarly, as Rodrigues (2001: 4) stresses, the European Employment Strategy was tailored to overcome differing views on how (if at all) to fight unemployment at the European level during the 1997 special summit in Luxembourg. Relying on soft law facilitated coming to an agreement.[21] Rather than search for a compromise on substantive issues, governments opted for a procedural solution. They initiated a process of mutually monitoring their otherwise discrete decisions. Hence, a reason for the choice of soft law is that it seems particularly suited to overcoming disagreements.

Moreover, soft law is attractive for national governments as it limits sovereignty losses. States rely on multilateral surveillance to coordinate their policies in the absence of 
enforceable, binding rules.

In contrast, " $[\mathrm{t}]$ he term hard law ... refers to legally binding obligations that are precise (or can be made precise through adjudication or the issuance of detailed regulations) and that delegate authority for interpreting and implementing the law. Although hard law is not the typical international legal arrangement, a close look at this institutional form provides a baseline for understanding the benefits and costs of all types of legalization. By using hard law to order their relations, international actors reduce transaction costs, strengthen the credibility of their commitments, expand their available political strategies, and resolve problems of incomplete contracting. Doing so, however, also entails significant costs: hard law restricts actors' behavior and even their sovereignty." (Abbott/Snidal 2000: 421-422)

In reducing the degree to which rules are binding, precise and authoritative soft law offers a number of advantages to governments which avoid the costs of hard law. In particular, the Open Method of Coordination:

- allows for flexibility (policy initiatives can be adapted to the diverse institutional arrangements, legal regimes and national circumstances in the member states);

- minimizes sovereignty losses (member-state compliance remains essentially voluntary. Compliance is not enforceable);

- helps to overcome political resistance (flexible agreements may surmount member states' opposition to EU mandates considered too disruptive of or alien to national arrangements);

- facilitates the shifting of blame (it enables domestic actors to blame the EU for unpopular decisions);

- offers symbolic politics (new initiatives foster the impression of determination. European governments jointly take action against unemployment, social exclusion, and sluggish growth);

- avoids a loss of control (governments stay firmly in control of politics. Rather than enabling supranational organizations to follow their own agenda [principal-agent problem], member state's governments use the OMC to shield them from outside interference - unless this interference turns out to be domestically useful. An internationalization of domestic decisions strengthens executive actors [Wolf 1999; Moravcsik 1997]).

In sum, governments willingly adopt soft law because it increases their strategic room for maneuver in two-level games. Governments can effectively use their privileged position as agents of their national constituencies and principals to supranational actors (Schäfer 2002: 29-30).

\section{Conclusion: Effective Governance?}

This paper has compared the Open Method of Coordination to other procedures of policy coordination both within the European Union and in other international organizations. In contrast to the existing literature, it has argued that the OMC is but a subtype of multilateral surveillance. While this form of policy-making was not introduced to the EU until the 1990s, it has long been used in the OECD and the IMF. Hence, studies that exclusively focus on the EU have not only overstated the novelty of the OMC but also misread its potential consequences. Since the OMC resembles OECD and IMF procedures, it might not initiate further integration but instead turn out to assimilate the 
EU to more traditional international organizations. This outcome does not seem unlikely if we consider the EU's growing membership after enlargement. More diversity might block hard law in the future and leave soft law procedures as a feasible alternative. Multilateral surveillance is not primarily chosen for its effectiveness but for its capacity to facilitate compromises, substituting substantial agreements for procedural ones.

In comparison to IMF and OECD multilateral surveillance, the OMC's major innovation is the introduction of National Action Plans. They assign a more active role to national governments than the Economic Surveys, the Article IV Consultations or the Broad Economic Policy Guidelines do. However, the prime shortcoming is a lack of public awareness. As section 4 has argued, multilateral surveillance always builds on peer pressure as well as public pressure. Yet the second seems to be almost entirely absent from the European Employment Strategy and the Broad Economic Policy Guidelines. Instead, the message these processes convey is diverted: the recommendations are too numerous and too diverse. Despite claims to its openness, the OMC is a process only known to experts.

Moreover, there are further shortcomings to a predominantly voluntary process that have not received enough attention. Most importantly, any potential impact depends more on the will of national governments than it does with harder forms of policy-making. There is nothing in the OMC that impedes welfare retrenchment. It neither prevents regime competition nor overcomes purely national alliances of "competitive solidarity" (Streeck 1999). Hence, the aim of the recent Dutch agreement to keep wages below the level of yearly inflation plus productivity gains could be to beggar its neighbors, opting for price competition rather than quality competition. This strategy of course only works if the neighbors do not respond in kind. If they do, the competitive edge won by this move will be lost - necessitating further action. If 'Social Europe' is about avoiding a competitive lowering of national welfare standards, the OMC cannot be the ultimate answer.

Furthermore, the effectiveness of the OMC depends on supportive actors. Between 1997 and 2001 - when many of the OMC processes were initiated - there was a historical high of governments led by social democrats (see Schäfer 2004). In 1999, eleven out of 15 member states had social democratic prime ministers. In Lisbon, led by Prime Minister Guterres of Portugal, there were still nine center-left governments. This situation by now has ceased. Presently, their number has declined to four in the EU-15. That might well mean that the momentum for combining equity and efficiency in welfare state reform is lost. If governments opt for further retrenchment, the OMC will not stem the tide.

Hence, in terms of effectiveness a comparative account of soft coordination leads to a less sanguine interpretation than the one suggested by the current literature. A recent book on "The OECD and European Welfare States" (Armingeon/Beyeler 2004) reveals the extremely modest influence of the OECD Economic Surveys on national policies. This finding also raises doubts as to the potential of the EU's procedures of multilateral surveillance to induce change. Their capacity to do so seems severely limited by the inherent voluntarism of soft law, which is unable to oblige reluctant governments to change their policies.[22] Further research will have to answer the question of whether the differences of the procedures outlined in section 3 suggest a greater impact on the part of the OMC.

Considering the $\mathrm{OMC}$ as a subtype of multilateral surveillance opens up a range of new questions and research avenues. If EU policy coordination does not categorically differ from the work of other international organizations, we are inclined to ask why the EU 
adopts their instruments at a time when integration in monetary and fiscal policy is superseding traditional forms of inter-state cooperation. What explains this asymmetry: a functional logic or political imperatives? Furthermore, an empirically derived model of multilateral surveillance invites further comparison. For example, the WTO Trade Policy Review Mechanism resembles the procedures described in this paper. A more detailed study could draw on the six criteria put forward in section 4 to analyze this policy-making instrument. In addition, there are a number of other OMC procedures within the European Union which can be compared to the BEPG and the EES, or to the OECD and IMF procedures. Does their effectiveness co-vary with the emphasis on certain elements of multilateral surveillance? Another strand of research might investigate why these organizations introduced soft law procedures at very different moments in time. Are there any common reasons across cases/ organizations? Distancing ourselves from a sui generis vision of EU policy-making allows us to tackle these questions, which must for now be left to subsequent research.

\section{Literature}

Abbott, Kenneth W. / Duncan Snidal, 2000: Hard and Soft Law in International Governance. In: International Organization 54, 421-456.

Armingeon, Klaus / Michelle Beyeler, 2004: The OECD and European Welfare States. Cheltenham: Edward Elgar.

Aubrey, Henry G., 1967: Atlantic Economic Cooperation. The Case of the OECD. New York/Washington/London: Frederick A. Praeger.

Begg, Iain / Dermot Hodson / Imelda Maher, 2003: Economic Policy Coordination in the European Union. In: National Institute Economic Review No. 183, 66-77.

Biagi, Marco, 1998: The implementation of the Amsterdam Treaty with regard to employment: co-ordination of convergence? In: IIRA (ed.), 11th World Congress: Developing competitiveness and social justice: the interplay between institutions and social partners. Bologna, 23-33.

Bordo, Michael D. / Harold James, 2000: The International Monetary Fund: Its Present Role in Historical Perspective. In: NBER Working Paper Series No. 7724.

Borrás, Susana / Bent Greve, 2004: Concluding remarks: New method or just cheap talk? In: Journal of European Public Policy 11, 329-336.

Borrás, Susana / Kerstin Jacobsson, 2004: The open method of co-ordination and new governance patterns in the EU. In: Journal of European Public Policy 11, 185-208.

Börzel, Tanja A., 2003: Shaping and Taking EU Policies: Member State Responses to Europeanization. In: Queen's Papers on Europeanization 2/2003.

Boughton, James M., 2001: Silent Revolution. The International Monetary Fund 19791989. Washington D.C.: International Monetary Fund.

Büchs, Milena / Dawid Friedrich, 2004: Surface Integration - The NAPs for employment and social policy coordination in Germany. In: Jonathan Zeitlin / Philippe Pochet / Lars Magnusson (eds.), Opening the Open Method of Coordination. Brussels: Peter Lang (forthcoming).

Council of the European Union, 2003: Broad Economic Policy Guidelines for the period 2003-2005. Luxembourg: Office for the Official Publications of the European Communities.

Crow, John / Ricardo Arriazu / Niels Thygesen, 1999: External evaluation of IMF surveillance: Report by a Group of Independent Experts. Washington: International Monetary Fund.

de Búrca, Gráinne / Jonathan Zeitlin, 2003: Constitutionalising the Open Method of Coordination. What Should the Convention Propose? In: CEPS Policy Brief 31, 
March 2003.

de la Porte, Caroline, 2002: Is the Open Method of Coordination appropriate for organising activities at European level in sensitive policy areas? In: European Law Journal 8, 38-58.

de la Porte, Caroline / Philippe Pochet (eds.), 2002a: Building Social Europe through the Open Method of Co-ordination. Brussels et al.: PIE Lang.

de la Porte, Caroline / Philippe Pochet, 2002b: Introduction. In: Caroline de la Porte / Philippe Pochet (eds.), Building Social Europe through the Open Method of Coordination. Brussels et al.: PIE Lang, 11-26.

de la Porte, Caroline / Philippe Pochet, 2004: The European Employment Strategy: existing research and remaining questions. In: Journal of European Social Policy 14, 71-78.

de Vries, Margaret Garritsen, 1985: The International Monetary Fund 1972-1978. Cooperation on Trial. Volume II: Narrative and Analysis. Washington, D.C.: International Monetary Fund.

Dostal, Jörg Michael, 2004: Campaigning on expertise: how the OECD framed EU welfare and labour market policies - and why success could trigger failure. In: Journal of European Public Policy 11, 440-460.

Eberlein, Burkhard / Dieter Kerwer, 2002: Theorising the New Modes of European Union Governance. In: European Integration online Papers (EIoP) 6.

European Commission, 2002a: 2002 Broad Economic Policy Guidelines. In: European Economy 4/2002.

European Commission, 2002b: Co-ordination of economic policies in the EU: a presentation of key features of the main procedures. In: Euro Papers No. 45. European Commission, 2002c: Taking stock of five years of the European Employment Strategy. In: Communication from the Commission to the Council, the European Parliament, the Economic and Social Committee and the Committee of the Regions. COM (2002) 416 final.

European Commission, 2003: Broad Economic Policy Guidelines (for the 2003-05 period). In: European Economy 4/2003.

European Council, 2000: Presidency Conclusions. Lisbon, 23 and 24 March 2000.

Ferrera, Maurizio / Anton Hemerijck / Martin Rhodes, 2000: The Future of Social Europe: Recasting Work and Welfare in the New Economy. Lisbon: Report for the Portuguese Presidency of the European Union.

Goetschy, Janine, 1999: The European Employment Strategy: Genesis and Development. In: European Journal of Industrial Relations 5, 117-137.

Grande, Edgar, 2000: Multi-Level Governance: Institutionelle Besonderheiten und Funktionsbedingungen des europäischen Mehrebenensystems. In: Edgar Grande / Markus Jachtenfuchs (eds.), Wie problemlösungsfähig ist die EU? Regieren im europäischen Mehrebenensystem. Baden-Baden: Nomos, 11-30.

Harper, Richard H. R., 1998: Inside the IMF. An Ethnography of Documents, Technology and Organisational Action. San Diego: Academic Press.

Hix, Simon, 1998: The study of the European Union II: the 'new governance' agenda and its rival. In: Journal of European Public Policy 5, 38-65.

Hodson, Dermot, 2004: Macroeconomic co-ordination in the euro-area: the scope and limits of the open method. In: Journal of European Public Policy 11, 231-248.

Hodson, Dermot / Imelda Maher, 2001: The Open Method as a New Mode of Governance: The Case of Soft Economic Policy Coordination. In: Journal of Common Market Studies 39, 719-746.

IMF, 2002: IMF Reviews Experience and Next Steps in the Fund's Transparency Policy. In: Public Information Notice 02/111.

IMF, 2003: Transparency at the IMF. In: A Factsheet April 2003. 
Jachtenfuchs, Markus, 2001: The Governance Approach to European Integration. In: Journal of Common Market Studies 39, 245-264.

Jacobsson, Kerstin, 2001: Employment and Social Policy Coordination. A New System of EU Governance: Paper for the Scancor workshop on 'Transnational regulation and the transformation of states,' Stanford, 22-23 June 2001.

Jacobsson, Kerstin / Herman Schmid, 2002: Real integration or just formal adaptation? On the implementation of the National Action Plans for Employment. In: Caroline de la Porte / Philippe Pochet (eds.), Building Social Europe through the Open Method of Co-ordination. Brussels et al.: PIE Lang.

Kenner, Jeff, 1999: The EC Employment Title and the 'Third Way': Making Soft Law

Work? In: The International Journal of Comparative Labour Law and Industrial

Relations 15, 33-60.

Laird, Sam, 1999: The WTO’s Trade Policy Review Mechanism - From Through the Looking Glass. In: The World Economy 22, 741-764.

Marcussen, Martin, 2004: Multilateral surveillance and the OECD: playing the idea game. In: Klaus Armingeon / Michelle Beyeler (eds.), The OECD and European Welfare States. Cheltenham: Edward Elgar, 13-31.

Meyer, Christoph O., 2003: Towards a Europeanization of Socio-Economic Discourses?

A Study of Quality Press Coverage of Economic Policy Coordination since Amsterdam. Contribution to the EUROPUB Conference 'Europeanization of Public Spheres? Political Mobilisation, Public Communication, and the European Union' at the WZB, June 20-22, 2003, Berlin.

Moravcsik, Andrew, 1997: Warum die Europäische Union die Exekutive stärkt: Innenpolitik und internationale Kooperation. In: Klaus-Dieter Wolf (ed.), Projekt Europa im Übergang? Probleme, Modelle und Strategien des Regierens in der Europäischen Union. Baden-Baden: Nomos, 211-269.

Noaksson, Niklas / Kerstin Jacobsson, 2003: The Production of Ideas and Expert

Knowledge in OECD. The case of the OECD Jobs Strategy in contrast with the EU Employment Strategy. Score research report, No 7. Stockholm.

Nottage, Hunter, 2002: Peer Review: Merits and Approaches in a Trade and Competition Context. Paris: Joint Group on Trade and Competition, OECD.

OECD, 2002a: Economic Development and Review Committee: Agreed Principles and Practices. Paris: OECD, (ECO/EDR/DIV(2002)5).

OECD, 2002b: Germany. In: OECD Economic Surveys Vol. 2002, Supplement No. 4 January 2003.

Pagani, Fabrizio, 2002: Peer review: A tool for co-operation and change. An Analysis of an OECD working method. Paris: OECD.

Pochet, Philippe / Caroline de la Porte / Graham Room, 2001: Social benchmarking, policy making and new governance in the EU. In: Journal of European Social Policy 11, 291-307.

Radaelli, Claudio M., 2003: The Open Method of Coordination: A new governance architecture of the European Union? Rapport 1/2003. Stockholm: Swedish Institute for European Policy Studies (SIEPS).

Régent, Sabrina, 2002: The Open Method of Co-ordination: A supranational form of governance? In: IILS Discussion Paper DP/137/2002.

Risse, Thomas / Maria Green Cowles / James Caporaso, 2001: Europeanization and Domestic Change: Introduction. In: Maria Green Cowles / James Caporaso / Thomas Risse (eds.), Transforming Europe. Europeanization and Domestic Change. Ithaca/London: Cornell University Press, 1-20.

Rodrigues, Maria João, 2001: The Open Method of Coordination as a New Governance Tool. In: Mario Telò (ed.), L'evoluzione della governance europea, special issue of Europa/Europe. Rome, 96-107. 
Rodrigues, Maria João, 2002: Introduction: for a European strategy at the turn of the century. In: Maria João Rodrigues (ed.), The new knowledge economy in Europe: a strategy for international competitiveness and social cohesion. Cheltenham: Edward Elgar, 1-27.

Sabel, Charles F. / Jonathan Zeitlin, 2003: Active Welfare, Experimental Governance, Pragmatic Constitutionalism: The New Transformation of Europe. Draft prepared for the International Conference of the Hellenic Presidency of the European Union, 'The Modernisation of the European Social Model \& EU Policies and Instruments.' Ioannina, Greece, 21-22 May 2003.

Schäfer, Armin, 2002: Vier Perspektiven zur Entstehung und Entwicklung der

“Europäischen Beschäftigungspolitik.” In: MPIfG Discussion Paper 02/9, Cologne.

Schäfer, Armin, 2004: Beyond the Community Method: Why the Open Method of

Coordination Was Introduced to EU Policy-making. In: European Integration online Papers (EIoP), Vol. 8 (2004), N 13. <http://eiop.or.at/eiop/texte/2004-013a.htm>

Stinchcombe, Arthur L., 1968: Constructing Social Theories. New York et al.: Harcourt, Brace \& World.

Streeck, Wolfgang, 1995: Neo-Voluntarism: A New European Social Policy Regime? In: European Law Journal 1, 31-59.

Streeck, Wolfgang, 1999: Competitive Solidarity: Rethinking the "European Social Model.” MPIfG Working Paper 99/8, September 1999, Cologne.

Trubek, David M. / James Mosher, 2001: New Governance, EU Employment Policy, and the European Social Model. In: Jean Monnet Working Paper 6/01.

Trubek, David M. / James S. Mosher, 2003: New Governance, Employment Policy, and the European Social Model. In: Jonathan Zeitlin / David Trubek (eds.), Governing Work and Welfare in a New Economy: European and American Experiments. Oxford: Oxford University Press, 33-58.

Verdun, Amy, 2003: An American/European divide in European integration studies: bridging the gap with international political economy. In: Journal of European Public Policy 10, 84-101.

Visser, Jelle, 2002: Is the European Employment Strategy the Answer? Paper prepared for the NIG Workshop: "Governability in Post-Industrial Societies: The European Experience." Utrecht School of Governance, 26-27 April 2002.

Wallace, Helen, 2000: The Institutional Setting: Five Variations on a Theme. In: Helen Wallace / William Wallace (eds.), Policy-Making in the European Union. Oxford: Oxford University Press, 3-37.

Wolf, Klaus Dieter, 1999: Defending state autonomy. Intergovernmental governance in the European Union. In: Beate Kohler-Koch / Rainer Eising (eds.), The transformation of governance in the European Union. London: Routledge, 231-248.

Zeitlin, Jonathan, 2004: The Open Method of Coordination: Improving the Legitimacy and Effectiveness of EU Governance. Presentation to 14th International Conference of Europeanists. Chicago, 11-13 March.

\section{Endnotes}

1

An earlier version of this paper was presented at the Conference of Europeanists: 'Europe and the World: Integration, Interdependence, Exceptionalism?' Chicago, March 11-13, 2004. I would like to thank Burkhard Eberlein, Susanne Schmidt, and Cornelia Woll for their helpful comments.

2

For a similar account, see Börzel (2003: 1-3).

3

For a discussion of the sui generis assumption of EU studies, see Verdun (2003: 85-88). 
In a more critical vein Trubek and Mosher (2003: 47-48) stress that the OMC has got a potential for policy-learning which as yet has not been realized, however.

5

More generally on functional explanations, see Stinchcombe (1968: 80-93).

6

"To date, most analyses on OMC have underlined the difficulty of evaluating its effects nationally. Indeed, OMC's effects on Europeanization - the manner in which domestic policy areas become subject to European policy-making - and European Integration - the process in which countries pool sovereignty under the auspices of the European Union - are difficult to discern" (de la Porte/Pochet 2002b: 13).

\section{7}

Brief comparisons of the EES and the OECD Jobs Strategy can be found in Visser (2002: 3-4) and Noaksson/Jacobsson (2003). See also recently Dostal (2004).

8

The adjective "multilateral" can refer either to the object or the subject of surveillance. I take it to mean the former as these processes are geared towards multilateral discussion of national policies. The latter would in contrast mean the discussion of several states' policies and their interdependencies. Of course, all three organizations conduct both kinds of surveillance.

9

For an example, see OECD (2002b).

10

In interviews with OECD staff it was stressed that in future they will put even more emphasis on the bilateral discussion to sharpen the organization's profile in policy advising. As the OECD faces competition in this area by the European Union, they want to use the presumed comparative advantage of economic expertise.

11

The conduct of EDRC multilateral surveillance is described in OECD (2002a).

12

For a vivid account of a mission, see Harper (1998: chapter 8).

13

Notions like "most," "many," "some" or "a few directors" indicate how great a disagreement exists.

14

This is, however, a recent development and results from a conscious effort to increase transparency. Cf. IMF (2002; 2003).

15

If the EPC or the EFC do not agree, they transfer the controversial issue to the ECOFIN-Alternates. In rare cases, even the ECOFIN Council will discuss contentious recommendations. In principle, a qualified majority decision is possible, but in reality members seek consensus.

16

For an account of its origins and development, see Goetschy (1999) and de la Porte (2002).

17

For example, they also apply to the WTO's Trade Policy Review Mechanism. See Laird (1999).

18

For example, the publication of the most recent Economic Survey of Germany was the second news item on the main German news program (Tagesschau, 5 August 2004). It included an interview with an OECD official as well as reactions of both government and opposition parties. To my knowledge, neither the EES nor the BEPG have ever received similar attention in Germany.

19

However, an OECD economist argued during an interview that he considered the length of the 
Economic Surveys to be disadvantageous. He commended the EU for producing short accounts with a clear message.

\section{0}

However, an OECD economist argued during an interview that he considered the length of the Economic Surveys to be disadvantageous. He commended the EU for producing short accounts with a clear message.

\section{1}

Kenner (1999) characterizes the Employment Strategy as "soft law."

22

This does not mean that voluntarist procedures are necessarily ineffective or mere "cheap talk" (Borrás/Greve 2004). Sometimes multilateral surveillance might be effective because governments strongly support the goals or encounter little domestic opposition. However, if this is the case, a joint European approach might be neither necessary nor the most efficient way to distribute information.

Copyright (C) 2004 Armin Schäfer

No part of this publication may be reproduced or transmitted without permission in writing from the author.

Jegliche Vervielfältigung und Verbreitung, auch auszugsweise, bedarf der Zustimmung des Autors.

MPI für Gesellschaftsforschung, Paulstr. 3, 50676 Köln, Germany 